\title{
Dear colleagues!
}

The Scientific committee of

The Annual International Specialized Scientific and Practical Conference "Resource and Energy Saving Technologies of Production and Packing of Food Products as the Main Fundamentals of Their Competitiveness"

invites you

to participation in the Conference

and publication of your scientific research.

The Conference is hold every year in September in the frames

of Annual International Exhibitions

"Equipment and Technologies for the Food Industry"

and

"Packaging Technologies and Equipment"

In the frame of Conference there are published:

1. Abstract Book

2. Proceeding Book of Articles

Every article gets DOI identifier.

Abstracts and articles should be sent by email to:

Oleksiigubenia@gmail.com

\section{Requirements for the Abstract}

Language - English

Recommended size - 1-2 pages in Microsoft Word.

All article elements should be in Times New Roman, font size 14, 1 line intervals, margins on both sides $2 \mathrm{~cm}$.

The structure of the Abstract:

- Title

- Authors (full name and surname)

- Institution, where the work performed.

- Text of the Abstract. The Abstract should contain the following obligatory parts: Introduction, Materials and methods, Results and discussion,

- Conclusion.

- Key words.

The information about the author (Name, surname, scientific degree, place of work, email and contact phone number).

Deadline of Abstract submission - August, 20 


\section{Requirements for article}

Language - English

Recommended size of the article - 7-12 pages.

All article elements should be in Times New Roman, font size 14, 1 line intervals, margins on both sides $2 \mathrm{~cm}$.

The structure of the article:

- Title

- Authors (full name and surname)

- Institution, where the work performed.

- Abstract (the half of page)

- Key words.

- Text of Article

- References

- Information about the author (Name, surname, scientific degree, place of work, email and contact phone number).

The main body of the article should contain the following obligatory parts:

- Introduction

- Materials and methods

- Results and discussion

- Conclusion

- References

If you need you can add another parts and divide them into subparts.

Figures should be made in graphic editor, the font size 14 .

The background of the graphs and charts should be only in white color. The color of the figure elements (lines, grid, text) - in black color.

Figures and EXCEL format files with graphs additionally should submit in separate files.

Photos are not appropriate to use.

\section{Example of References:}

\section{Article:}

Popovici C., Gitin L., Alexe P. (2013), Characterization of walnut (Juglans regia L.) green husk extract obtained by supercritical carbon dioxide fluid extraction, Journal of Food and Packaging Science, Technique and Technologies, 2(2), pp. 104-108.

Book:

Deegan C. (2000), Financial Accounting Theory, McGraw-Hill Book Company, Sydney.

Web:

Ukrainian Food Journal, Available at: http://ufj.ho.ua/

Deadline of Abstract submission - December, 20 
Наукове видання

\author{
Resource and Energy Saving Technologies \\ of Production and Packing of Food Products \\ as the Main Fundamentals of Their Competitiveness: \\ Proceedings of the 7th International Specialized \\ Scientific and Practical Conference, \\ September 12, 2019.
}

Підп. до друку 27.12.19 р. Обл.-вид. арк. 9.26

Наклад 100 пр. Вид. № 18н/19

НУХТ. 01601 Київ-33, вул. Володимирська, 68

Свідоцтво про реєстрацію серія ДК № 1786 від 18.05.04 p. 